高分子論文集 (Kobunshi Ronbunshu), Vol. 39, No. 4, pp. 203-211 (Apr., 1982)

\title{
セグメントポリウレタンの血液適合性と疲労挙動に及ぼす ミクロ相分離搆造の影響
}

\author{
高原 淳*1 ・田下純一*1 ・梶山千里*1 ・高柳素夫*1
}

(受付 1981 年 10 月 24 日・審查終了 1982 年 1 月 31 日)

\begin{abstract}
要 旨人工心瀻用材料として注目を集めているBiomer と種々のソフトセグメント長を持つセグ メントポリウレタンのミクロ相分離構造を解析し, 血小板との相互作用及び疲労挙動を検討した。試料 の小角 $\mathrm{X}$ 線散乱像は長周期構造の存在を示し, ミク口相分雇構造を形成していることが明らかである. ソフトセグメントのポリテトラメチレングリコール (PTMG) の分子量を增加すると長周期は增大し, 粘弹性主分散域は低温にシフトし，かっウレタン基の水素結合分率は減少し，相分離状態がより完全 になった。相分離状態の完全な Biomer とPTMG の分子量 2000 のセグメントポリウレタンの場 合，試料表面に粘着した血小板数は少なく，その形態変化も抑制されている。試料の疲労強度は疲労 過程における平均七ステリシス損失で記述できる。疲労に伴いハードセグメントとンフトセグメント の部分的な混合が起こり相分離状態は不完全になった。
\end{abstract}

\section{1 腥言}

セグメンポリウレタンは，ハードセグメントとソフ トセグメントの繰り返しよりなるマルチブロック共重合 体である. ハードセグィントは, ジイソシフナートとジ アミンまたはジオールよりなり，水素結合により凝集し てハララリリタル的ドメインを形成する，ソフトセグメ ントは、ジイソシフナートとポリエステルジオールまた はポリエーテルジオールよりなり， ハードセグメントを 取り囲むマトリックスとなる1),2).

セグメントポリウレタンは，ハードセグメントドメイ ンが物理的な橋かけ点あるいは充てん剂としての機能を 発揮し，優れた力学的性質を示す. 更にセグメントポリ ウレタンは良好な抗血栓性を示す3), ことから現在ま でに多くの研究者によって人工血管泉), 人工心蔵ポンプ 用材料()，大動脈内バルーンポンプ7に応用されてきた。
しかしこれらの材料の抗血栓性のメカニズムは明ら かにされておらず，また，人工心䁍ポンプ用材料の安全 性の基準となる疲労特性と化学構造の関係についても解 明されていない。

本研究では, 種々のソフトセグメント長を有するセ グメントポリウレタンと人工心缄ポンプ用材料の Biomer®について, ミクロ相分離構造と化学構造の関 係を明らかにし, 更に, これらセグメントポリウレタン と血小板との相互作用及びその疲労挙動を検討した。

\section{2 実験}

\section{1 試料}

Table 1 に本研究で用いた試料を示す. “TU-Mn”の 略号で示したセグメントポリウレタンは, 分子量 $M_{n}$ の ポリテトラメチレングリコール (PTMG) 1 モルと 4, 4'ジフェニルメタンジイソシアナート (MDI) 2 モルをジ

$$
\begin{aligned}
& \text { Soft segment: } \\
& \mathrm{H} \mathrm{CH}_{2} \mathrm{CH}_{2} \mathrm{CH}_{2} \mathrm{CH}_{2} \mathrm{O}+\frac{\mathrm{C}}{\mathrm{O}}-\mathrm{H}-\mathrm{O}-\mathrm{CH}_{2}-\mathrm{O}-\mathrm{N}-\mathrm{C}-\mathrm{O}+\mathrm{H}_{\mathrm{n}} \text { (PTMG-MDI) }
\end{aligned}
$$

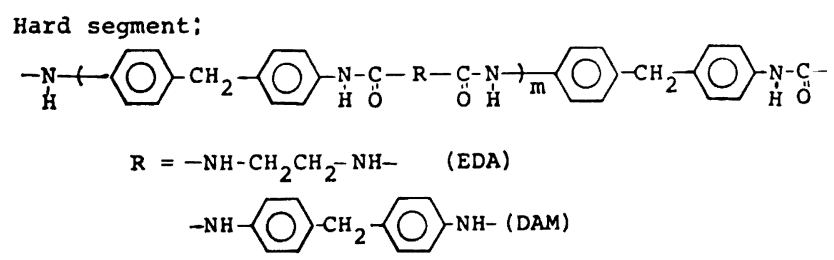

\footnotetext{
*1 九州大学工学部応用化学科（®812 福岡市東区箱崎6-10-1)
} 
Table 1. Chemical composition and domain size of samples ${ }^{\text {a) }}$

\begin{tabular}{lllccc}
\hline \hline \multirow{2}{*}{ Sample } & \multirow{2}{*}{ Soft segment $\left(M_{n}\right)$} & Hard segment & \multirow{2}{*}{$\begin{array}{c}\text { Long period } \\
(\mathrm{nm})\end{array}$} & & \multicolumn{2}{c}{ Domain size $(\mathrm{nm})$} \\
\cline { 5 - 6 } & & & Hard segment & Soft segment \\
\hline TU 856 & MDI-PTMG (856) & MDI-EDA/DAM(3/2) & 10.1 & 9.2 & 0.9 \\
TU 1350 & MDI-PTMG (1350) & MDI-EDA/DAM(3/2) & 10.6 & 9.2 & 1.4 \\
TU 2000 & MDI-PTMG (2000) & MDI-EDA/DAM(3/2) & 11.3 & 9.2 & 2.1 \\
Biomer ${ }^{\circledR}$ & MDI-PTMG (1800) & MDI-EDA & 9.8 & - & - \\
\hline
\end{tabular}

a) MDI, 4, 4'-diphenylmethane diisocyanate; PTMG, poly(tetramethylene glycol); EDA, ethylenediamine;

DAM, 4, 4'-diaminodiphenylmethane.

メチルアセトアミド (DMAc) 中で反応させて得たプレ ポリマーを 0.6 モルのェチレンジアミン (EDA) と 0.4 モルの水で鎖延長反応した試料である.ソフトセグメン トは PTMG-MDI の繰り返しょり，またハードセグメ ントは MDI-EDA 及び 4,4'-ジアミノジフェニルメタ ン(DAM) のランダムな繰り返しから構成されている.

$30 \mathrm{wt} \%$ DMAc 溶液の Biomer( ${ }^{33)}$,4) を Ethicon 社 より購入した，広角X線回折の結果より、ソフトセグメ ントは MDI-PTMG，またハードセグィントは MDIEDA が主成分であると推定される ${ }^{8)}$.

各試料は膜厚に応じて 1 10 wt\% の DMAc 溶液よ り溶媒蒸発法に上り $65^{\circ} \mathrm{C} て ゙ 48$ 時間製膜し減圧下で乾 燥した. 所定の寸法に切り出した後, 残留モノマーと溶 媒を除去するためにェタノール中で超音波洗浄を行い減 圧下で乾燥した．超音波洗浄による物性の低下がないこ とはあらかじめ確認した。

\section{2 試料のミクロ相分離構造の解析}

小角 $\mathrm{X}$ 線散乱 : 各試料の小角 $\mathrm{X}$ 線散乱像を Rotaunit (理学電機 (株)製) を用いて撮影した。

赤外吸収スペクトル：各試料薄膜の赤外吸収スペクト ルをPerkin Elmer 社製 567 型赤外分光器を用いて測 定した。

動的粘弾性：試料の動的粘弾性の温度依存性を Rheovibron DDVII-B 型（東洋ボールドウィン(株) 製) を用いて，11 Hz，窒素気流中で測定した。

応力ーひずみ挙動：各試料の応力ーひずみ挙動を Tensilon UTM III-500 (東洋ボールドゥィン(株)製)を用 いて, 温度 $295 \mathrm{~K}$, ゲージ間距離 $15 \mathrm{~mm}$ ，伸長速度 300 $\mathrm{mm} \min ^{-1}$ で測定した。

\section{3 試料と血小板の相互作用}

血小板は, 健康人の静脈よりクェン酸採血した全血よ り分離したヒト多血小板血墏 (PRP) を用いた．減圧下 で乾燥した試料を，PRP に浸せきした時に空気界面で の血獎タンパクの変性を防ぐために，リン酸綏衝溶液 (PBS, pH 7.4, I=0.2) に浸せきした。この試料をシリ コン化処理したペトリ血中の PRP に浸せきし， $310 \mathrm{~K}$ で 1 時間振とうした。試料は PBS で 3 回リンス後, グ
ルタルアルデヒドで固定し，脱水，乾燥後，金をスパッ タコーティングし, 走查型電子顕微鏡 (SEM: (株) 日立 製作所製 S-430) で試料表面に粘着した血小板数の算定 と形態観察を行った。

\section{4 疲労試験}

各試料の疲労試験を定ひずみ引張型疲労試験機を用い て, $9.26 \mathrm{~Hz}$ の周波数, $295 \mathrm{~K}$ の周团温度, 初期長 $15 \mathrm{~mm}$, 厚さ $1 \mathrm{~mm}$, 幅 $3 \mathrm{~mm}$ の試料に対して最小 伸長 $20 \sim 40 \%$, 動的伸長 40 110\% の条件下で行った. 本研究で用いた疲労試験機は, 疲労過程における応力信 号, ひず信号を連続的に検出し, 弾性率と力学的損失 正接 $\tan \delta$ をプリンターで自動記録できる ${ }^{9), 10)}$. 試料の 疲労回復を検討するため疲労直後の試料, 疲労後 24 時 間及び 7 日間室温で回復した試料の動的粘弾性の温度依 存性を測定した。また同様な試料の広角 $\mathbf{X}$ 線回折測定を 行った.

\section{3 結果及び考察}

\section{1 ミクロ相分離構造と化学楎造の関係}

3.1.1 小角 $X$ 線散乱 Fig. 1 (a) は Biomer® の高 伸長熱固定物 $(500 \%, 453 \mathrm{~K}, 2$ 分間) の小角 $\mathrm{X}$ 線散乱 像である. S.D. は伸長方向を示す. 子午線上の散乱は 長周期の存在を示す. ソフトセグメントの PTMG は後 述するように非晶状態であり長周期は Fig. 1 (b) のハー ドセグメントドメイン間の距離に対応する. ヘードセク メントドメインの側面方向の広がりの有限性より, セグ メントポリウレタンは, ードセグメントドメインをり フトセグメントのマトリックスが取り囲むいわゆるミク 口相分離構造を形成していることが明らかである。 Table 1 に小角X線散乱像より評価した長周期, ハード セグィント及びンフトセグィントドメインの寸法を示 す. ソフトセグメントの PTMG の分子量 $M_{n}$ と長周 期の間には直線関係が成立し， $M_{n}=0$ に補外した長周 期は $9.2 \mathrm{~nm}$ となった。これは八ードセグメントトイイ ンの 分子軸方向の大きさに 対応する. 長周期より 9.2 $\mathrm{nm}$ を差し引いた值はンフトセグメントドメインの大き さに対応する. TU856 の場合, ソフトセグメントド 


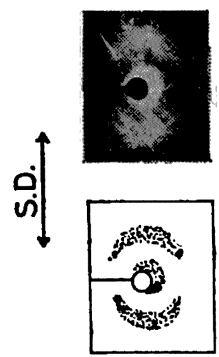

Biomer

(a)

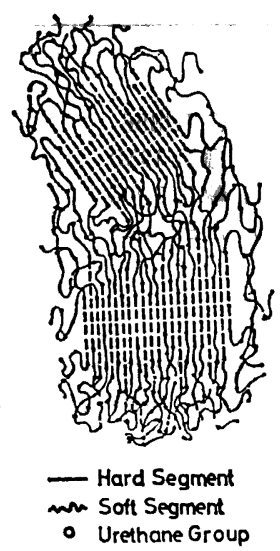

(b)
Fig. 1. (a) Small angle X-ray scattering pattern of Biomer stretched to $500 \%$ and heat treated at $453 \mathrm{~K}$ for $2 \mathrm{~min}$. S.D. represents the stretching direction. (b) Schematic representation of microphase separated structure for segmented polyurethane.

インの大きさは $0.9 \mathrm{~nm}$ であり，この寸法はハードセグ メントドメインの実測のブロック性 5.8 を考慮して評価 した束縛回転モデル11)に基いたソフトセグメントの鎖端 間距離 $6.2 \mathrm{~nm}$ と比べて極めて小さい。この事実は, 八 ードセグメンとンフトセグメントの境界が明確でな く，互いに混合した相が存在することを示唆している。

3.1.2 赤外吸収スペクトル Fig. 2 は TU 856, TU 2000，及び Biomer® の赤外吸収スペクトルである．各 吸収帯は中山 ${ }^{12)}$ 及び石原ら ${ }^{13), 16)}$ の報告に従って帰属し た. ウレタン基の $\mathrm{C}=\mathrm{O}$ 伸縮振動による吸収は 1740 $\mathrm{cm}^{-1}$ と $1720 \mathrm{~cm}^{-1}$ に分裂しており，それぞれ水素結合 していないウレタン $\mathbf{C}=\mathbf{0}$ と水素結合したウレタン $\mathbf{C}=$ O に㷌属される ${ }^{12) ~ 14) . ~} \mathrm{~N}-\mathrm{H}$ 伸縮振動は $3320 \mathrm{~cm}^{-1}$ 付 近に単一ピークとして観測されることから $\mathrm{N}-\mathrm{H}$ のほ とんどすべてが水素結合に関与していることが明らかで ある。 また $1640 \mathrm{~cm}^{-1}$ のウレア基の吸収は単一ピークで あり，石原ら ${ }^{13), 14)}$ が重水素化により低波数にシフトす ることを指摘していることから水素結合に関与したウレ ア基の主として $\mathbf{C}=\mathbf{O}$ 伸縮からなると結論できる.

ウレタン基の水素結合分率は次式より評価できる.

A(HB $\left.1720 \mathrm{~cm}^{-1}\right) /\left\{\right.$ A(NHB $\left.1740 \mathrm{~cm}^{-1}\right)$

$$
\left.+\mathrm{A}\left(\mathrm{HB} 1720 \mathrm{~cm}^{-1}\right)\right\}
$$

ここで $\mathrm{A}\left(\mathrm{HB} 1720 \mathrm{~cm}^{-1}\right)$ と $\mathrm{A}\left(\mathrm{NHB} 1740 \mathrm{~cm}^{-1}\right)$ は各 หウレタン基の $\mathrm{C}=\mathrm{O}$ の水素結合した $\mathrm{C}=\mathbf{0}$ 伸縮及び 水素結合していない $\mathrm{C}=\mathbf{O}$ 伸縮振動の吸光度である.

Fig. 3 はウレタン基の $\mathrm{C}=\mathrm{O}$ の水素結合分率のソフト セクメントの PTMG の分子量依存性である. 各吸光度 はベースライン法より評価したものを用いた． PTMG

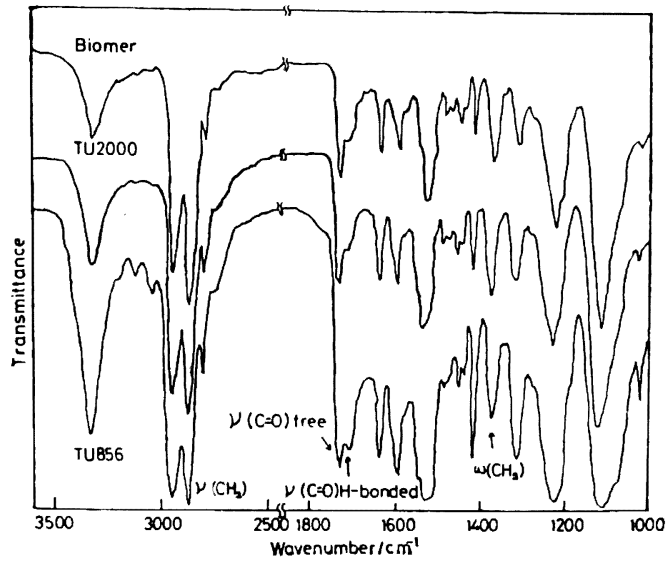

Fig. 2. Infrared spectra of TU 856, TU 2000, and Biomer®.

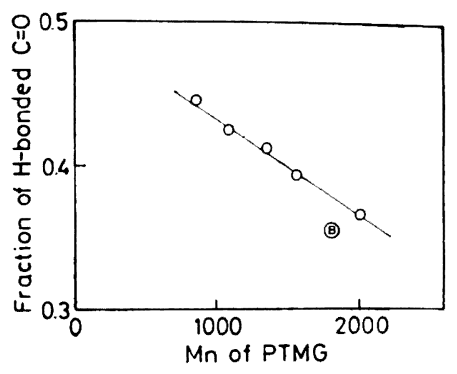

Fig. 3. The variation of extent of hydrogen bonding of urethane carbonyl with the molecular weight of poly(tetramethylene glycol) (PTMG) in soft segment. (B) denotes Biomer ${ }^{\circledR}$.

の $M_{n}$ の增加とともに, ウレタン基の $\mathrm{C}=\mathrm{O}$ の水素結 合分率は減少した．この事実は，ウレタン基どうしの水 素結合する確率が PTMG 鎖が長くなると減少すること を示している. ウレタン基はソフトセグメントドメイン 内やハードセグメントの末端に存在するので, PTMG の $M_{n}$ の減少とともに, ハードセグメントとンフトセ グメントの部分的な混合が著しくなると考えられる.

3.1.3 動的粘弾性 Fig. 4 は TU- $M_{n}$ のセグメント ポリウレタンと Biomer®の動的貯蔵弾性率， $E^{\prime}$ と損失 弾性率, $E^{\prime \prime}$ の温度依存性である. $150 \mathrm{~K}$ 付近に PTMG のメチレンシークェンスの局所運動に起因する $\gamma$ 吸収 が, 200 250 K には PTMG のミクロブラウン運動に 起因する $\alpha_{\mathrm{a}}$ 吸収が観測された， $\alpha_{\mathrm{a}}$ 吸収ピークはPTMG の $M_{n}$ の増加とともに低温側に移動し，ピークの立ち上 りもシャープになった. $M_{n} \geqq 1350$ の場合には $250 \mathrm{~K}$ 付 近に冷却時に生じた PTMG 結晶相の融解に起因する $\alpha_{\mathrm{f}}$ 吸収が $\alpha_{\mathrm{a}}$ 吸収のショルダーとして観測された。.Fig. 4 の結果は, PTMG の $M_{n}$ が大きいほど八ードセグメン トとソフトセグメントの部分的な混合が小さくなり，相 


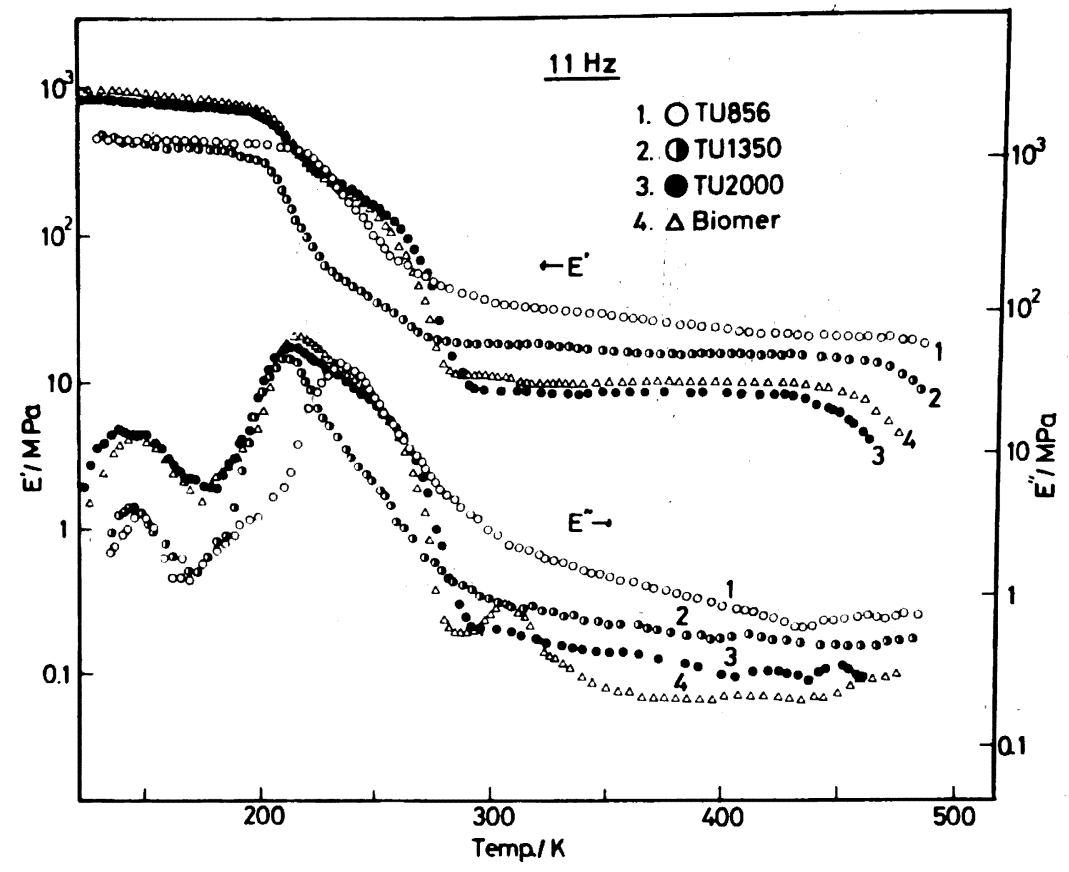

Fig. 4. Temperature dependences of $E^{\prime}$ and $E^{\prime \prime}$ for Biomer ${ }^{\circledR}$, TU856, TU1350, and TU2000.

分離状態がより完全になることを示唆しており，上記の 赤外吸収スペクトルの結果と一致する．Biomer®の場 合, $\alpha_{\mathrm{a}}$ 吸収之 $\alpha_{\mathrm{s}}$ 吸収域の挙動は TU 2000 とよく対応 している， $\alpha_{\mathrm{a}}$ 吸收極大温度の PTMG の $M_{n}$ 依存性よ り Biomer® の PTMG の $M_{n}$ は 1800 程度であると評 価された。 また，Biomer®は $310 \mathrm{~K}$ 付近にある種の吸 収が観測された，PTMG $\left(M_{n}=1900\right)$ と MDI 及び EDA より合成した試料にはこの吸収が観測されなかっ たことからハードセグメントに EDA 以外の異種の鎖延 長剤を含む可能性が示㖫される。一方， $450 \mathrm{~K}$ 近傍での $E^{\prime}$ の低下は TU 2000 より高温側で起こっており， メ ドセグメントの EDA の分率は，TU2000 より高く凝 集性が強いことが明らかである.

3.1.4 応力ーひずみ举動 Fig. 5 に各試料の応力ーひ ず曲線を示す. PTMG の $M_{n}$ の增加とともに弾性率 と引張強度は減少，破断伸びは增加した。これらの結果 はハードセグメントト゚メインが橋かけ点あるいは充てん 剤として働き,ソフトセグメントが網目鎖に対応する 高次組織の存在を示惨している. Biomer®はPTMGの $M_{n}$ が 1800 と大きいにもかかわらずその破断強度が著 しく大きいのは，ハードセグメント中の EDA の分率 が高く，強く凝集しだヘードセグメントドメインを形成 することによると考えられる.

以上の結果より, ソフトセグィントの PTMG の $M_{n}$
の小さいものは, ソフトセグィントの大部分がンードセ グメントから何らかの相互作用を受けており，そのた め, $\alpha_{\mathrm{a}}$ 吸収は高温側に存在し, PTMG は冷却しても結 晶化しない。他方, PTMG の $M_{n}$ が大きくなると, PTMG は冷却時に結晶化し, 非晶相に属する PTMG 分子鎖は十分に緩和したコンフォメーションをとってお $\eta ， \alpha_{\mathrm{a}}$ 吸収は低温側に観測される。すなわち，PTMG の $M_{n}$ の增加は相分離の状態を完全にする. 最近, Wilkes らはセグメントポリウレタンの PTMG の $M^{n}$ の小さいものは, ハードとソフトセグメント相の電子密 度の差が小さく界面層の厚いことを明らかにしだ5)。こ の結果は, 上述の実験結果とよく対応している。また, これらの結果は, Krause のマルチブロック共重合体に 関するミクロ相分離の理論 ${ }^{16)}$ とよ対応し，セグメント 長の增加（PTMG の $M_{n}$ の増加）とともに相分離状態 がより完全になることを示している.

\section{2 試料と血小板の相互作用}

Fig. 6 は各試料の製膜時の空気面 (AFS) とガラス面 (SFS) に粘着した血小板の走査型電子顕微鏡写真であ る. Biomer® と TU 2000 の場合粘着した血小板は円盤 状を保っており血液適合性は良好である。ガラス上では 血小板の粘着数も多く，偏平化・凝集が著しい. TU 856 と TU 1350 の場合, 血小板粘着数は比較的多く, 傦足 形成・凝集が観察された，TU-M $M_{n}$ のセグメントポリウ 


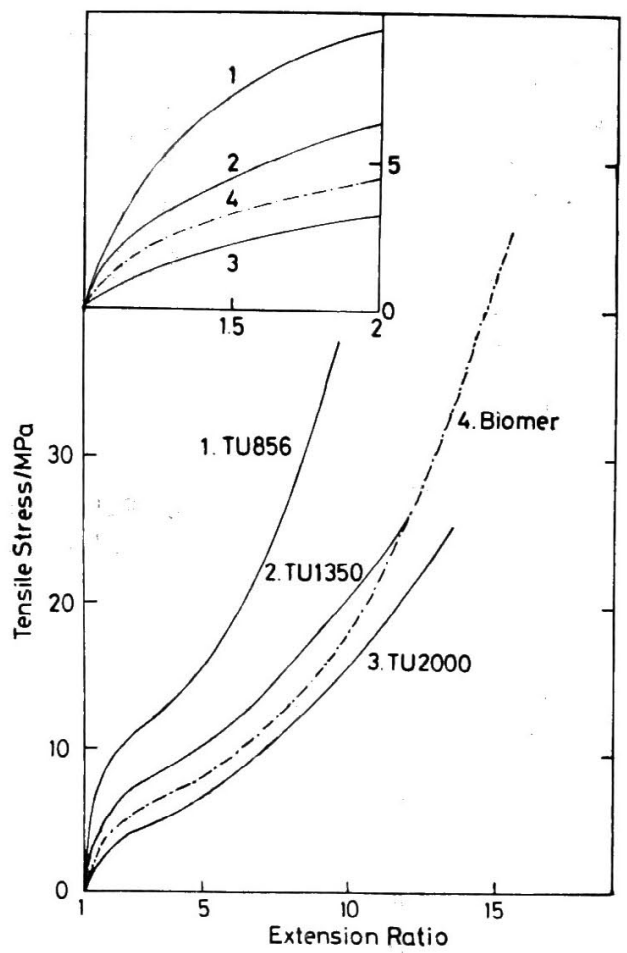

Fig. 5. Stress-strain curves for TU 856, TU 1350 , TU 2000 and Biomerß at 295K. Initial gauge length and extension rate are $15 \mathrm{~mm}$ and $300 \mathrm{~mm} \mathrm{~min}^{-1}$, respectively.

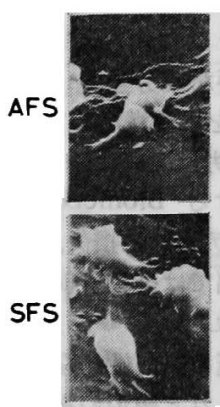

TU856

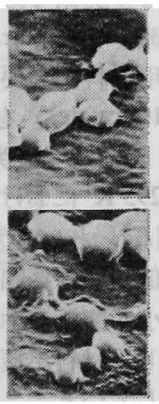

TU1350
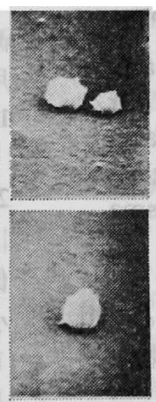

TU2000
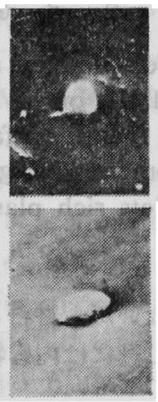

Biomer

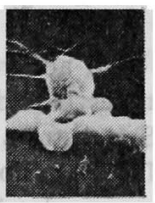

Glass

$\stackrel{5 \mu \mathrm{m}}{ }$

Fig. 6. Scanning electron micrographs of blood platelets on AFS (air facing surface) and SFS (substrate facing surface) of TU 856, TU 1350, TU 2000, Biomer ${ }^{\circledR}$, and glass after incubation in human platelets rich plasma for $60 \mathrm{~min}$ at $310 \mathrm{~K}$.

レタンの場合, PTMG の $M_{n}$ が大きく, 相分離の完全 な試料で血液適合性は良好であった。

高分子材料と血小板の相互作用を定量的に把握するた め, 材料表面での粘着血小板の形態を Fig. 7 に示すよ らな三つの形態に分類した ${ }^{17), 187 .}$
I. 基質に弱く粘着し, 細胞本来の形態を保っている.

II. 偽足を数本出し, 基質と比較的強く粘着する.

III. 多数の偽足を形成，または偏平化し，基質に強 固に粘着する.

試料表面に粘着した血小板は, 材料との相互作用が弱け 


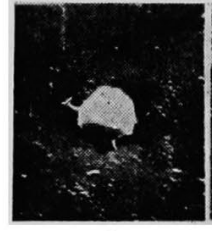

I

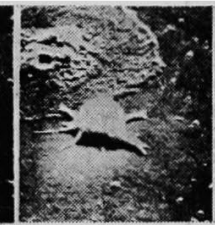

II

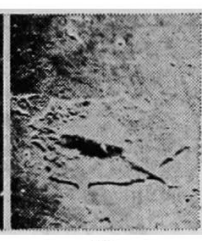

III
Fig. 7. Scanning electron micrographs of three types of adhered platelets on substratum. I, attachment of platelets at point of contact with substratum; II, centrifugal growth of filopodia; III, cytoplasmic webbing and flattening of the central mass.

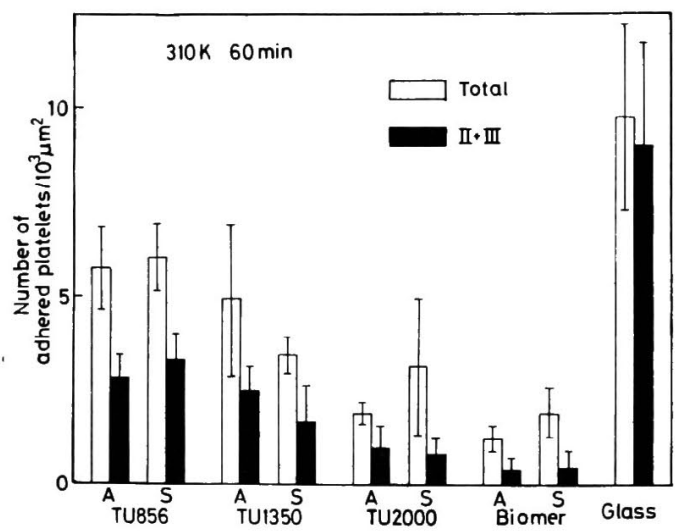

Fig. 8. Number of total adhered platelets and deformed platelets (types II and III) on A (air facing surface) and $\mathbf{S}$ (substrate facing surface) of TU 856, TU 1350, TU 2000, Biomer ${ }^{\circledR}$, and glass after incubation in human platelets rich plasma for $60 \mathrm{~min}$ at $310 \mathrm{~K}$.

れぱI型のままて時間的変化を示さないが，材料との相 互作用が強ければ, II, III 型と変形し遂には内容物を放 出し血小板血栓を生成する.

Fig. 8 は各試料表面 $10^{3} \mu \mathrm{m}^{2}$ 当たりの粘着血小板数 と II, III 型粘着血小板数である. Fig. 6 の SEM 像と よく対応しており, PTMG の $M_{n}$ が大きく相分離状態 の完全な Biomer® と TU 2000 で血小板の粘着・変形 が抑制された. Lyman らは，ミクロ相分離の大きさが 血獎タンパクの大きさ (短軸 $4 \sim 7 \mathrm{~nm}$, 長軸 $10 \sim 50 \mathrm{~nm}$ ) に一致した場合に良好な抗血栓性を発現することを指摘 した ${ }^{18)}$. 前述の小角X線散乱の結果より, $\mathrm{TU}-M_{n}$ の相 分離の大きさは $M_{n}$ を 856 から 2000 に増加しても, $1.2 \mathrm{~nm}$ しか増加せず，血墏タンパクの大きさのオーダ 一に比べて大きな変化ではない.しかしながら血液適合

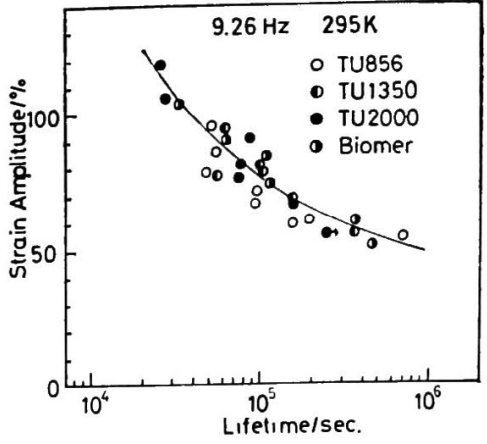

Fig. 9. Relationship between strain amplitude and fatigue lifetime for TU856, TU1350, TU2000, and Biomer(B) at $295 \mathrm{~K}$.

性は大きな違いを示した。 ハードセグメントのホモポリ マー20), あるいは結晶化したソフトセグメント ${ }^{21)}$ の血液 適合性が悪いといら報告を考虑すれば，TU 2000 及び Biomer@の血液適合性はミク口相分離構造に起因する ことが示唆される. 一方, TU- $M_{n}$ で, $M_{n}$ が 856 から 2000 に増加した場合の血液適合性の向上は, 相分離構 造の大きさと相分離状態の完全性が血液適合性の重要な 因子であることを示している.

\section{3 疲労举動}

3.3.1 ひずみ振幅と疲労寿命の関係 Fig.9は2 $295 \mathrm{~K}$ におけるセグメントポリウレタンのひずみ振幅と疲労寿 命の関係である.ひずみ振幅の増加とともに疲労寿命は 減少した. ヒグメントポリウレタンは，人工心臓ポンプ 用材料に必要な疲労強度（ひす゚み振幅 20\% で疲労寿命 $10^{8}$ cycles) を十分満足している.

3.3.2 疲労過程における動的粘弾性变化 Fig. 10 は $295 \mathrm{~K}$ における Biomer®の複素動的弹性率の絶対值, $\left|E^{*}\right|$ とヒステリシス損失, $\mathrm{H}$ の疲労時間依存性である. 低ひずみ振幅では破損直前に $\left|E^{*}\right|$ と $\mathrm{H}$ に各々極大と極 小が観湘された.この結果は変形方向に分子鎖が配向 し, 材料が極めて弾性的な状態となり破損したことを示 している.これと類似の挙動は既に高密度ポリエチレン $(\mathrm{HDPE})^{10)}$, 可塑化ポリ塩化ビ ニル $(\mathrm{p}-\mathrm{PVC})^{9)}$ 及び犬 緻密骨 ${ }^{22)}$ の場合にも観測されている.ひずみ振幅の増加 とともに, $\left|E^{*}\right|$ の極大, $\mathrm{H}$ 極小は消失した.

3.3.3 ヒステリシス損失と疲労寿命の関係 Fig. 11 は，TU 856, TU 2000，及び Biomer® の疲労過程に拈 ける平均ヒステリシス損失, $H_{\mathrm{av}}\left(=\left[\int_{0}^{t_{\mathrm{f}}} H_{\mathrm{dt}}\right] / t_{\mathrm{q}}\right)$ と疲 労寿命, $t_{t}$ の関係である. 低疲労寿命側での傾きが -1 であること, 疲労寿命無限大で $H_{\mathrm{av}}$ がある一定值 $H_{0}$ に 漸近する事実より (1) 式が経験的に得られるき0,10).

$$
\left(H_{\mathrm{av}}-H_{0}\right) \cdot t_{\mathrm{f}}=C
$$




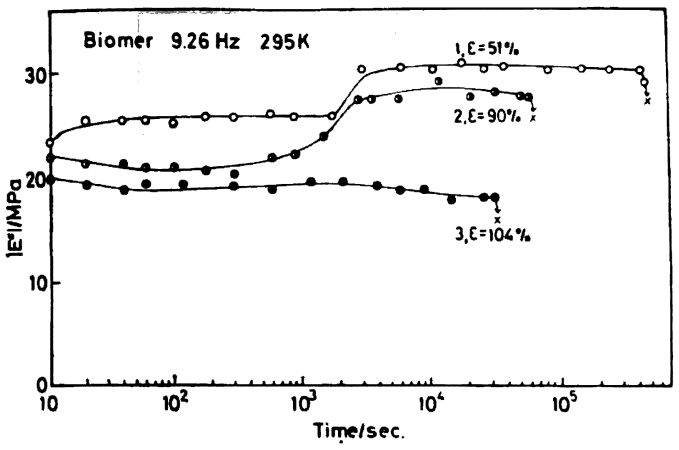

(a)

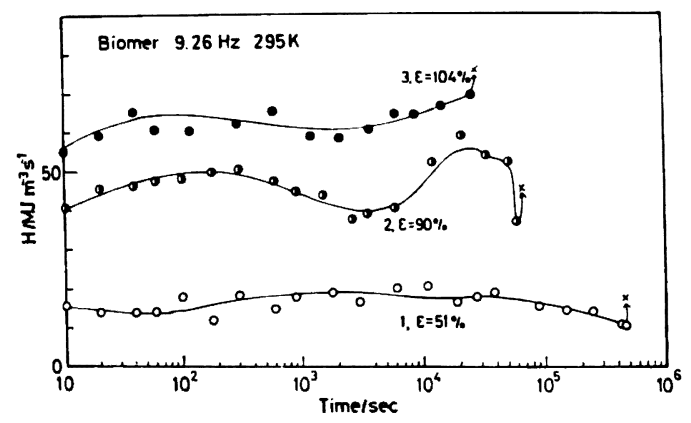

(b)

Fig. 10. The variations of absolute values of dynamic complex modulus, $\left|E^{*}\right|$ (a) and hysteresis loss, $H(\mathrm{~b})$ of Biomer ${ }^{\circledR}$ during the fatigue process at $295 \mathrm{~K}$.

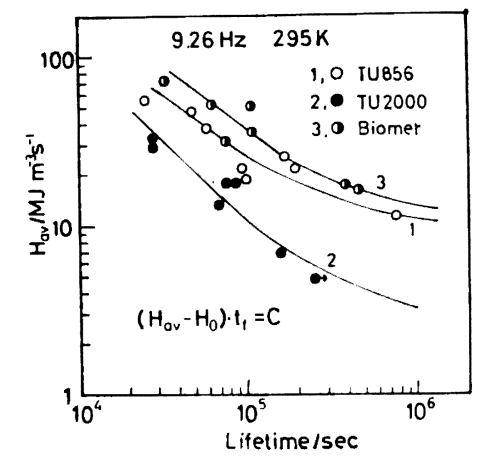

Fig. 11. Relationships between average hysteresis loss, $H_{\mathrm{av}}$ and fatigue lifetime for TU 856, TU 2000, and Biomer ${ }^{\circledR}$ at $295 \mathrm{~K}$.

ここで $\boldsymbol{C}$ は疲労破壊に至るまでの真のヒステリシス損 失の総和, $H_{0}$ は疲労限ヒステリシス損失であり, $H_{0}$ 以 下のヒステリシス損失を与える変形を材料に加えても疲

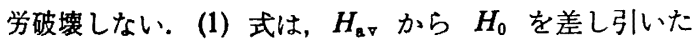
ものの総和が $C$ に達した時に疲労破壊が起こるという
Table 2. Values of net hysteresis loss upto fatigue failure, $C$ and hysteresis loss to fatigue limit, $H_{0}$ in eq. (1) for plasticized poly(vinyl chloride), high-density polyethylene, segmented polyurethanes (TU-Mn), Biomer ${ }^{B}$, and SBS elastomer

\begin{tabular}{lcc}
\hline \hline Sample & $C\left(\mathrm{~kJ} \mathrm{~m}^{-3}\right)$ & $H_{0}\left(\mathrm{~kJ} \mathrm{~m}^{-3} \mathrm{~s}^{-1}\right)$ \\
\hline p-PVC & $6.0 \times 10^{4}$ & 60 \\
& $6.0 \times 10^{4}$ & $87^{\mathrm{a})}$ \\
HDPE & $3.5 \times 10^{6}$ & 0 \\
& $2.3 \times 10^{7}$ & $0^{\mathrm{a})}$ \\
PEUU & & \\
TU 856 & $1.6 \times 10^{8}$ & $9.0 \times 10^{3}$ \\
TU 1350 & $1.1 \times 10^{9}$ & $5.5 \times 10^{3}$ \\
TU 2000 & $9.1 \times 10^{8}$ & $2.1 \times 10^{3}$ \\
Biomer & $2.6 \times 10^{8}$ & $1.0 \times 10^{4}$ \\
SBS & $2.2 \times 10^{7}$ & 0 \\
\hline
\end{tabular}

a) Under forced convection of air.

疲労破壊の基準を示している゚日,10). Table 2 は, TU$M_{n}$, Biomer ${ }^{\circledR}, \mathrm{SBS}$ ェラストマー, p-PVC ${ }^{()}, \mathrm{HDPE}^{10)}$ の $H_{0}$ と $C$ をまとめたものである.C の大きさは, ガ ラス状高分子, 結晶性高分子, ガラス状態のハードセグ メントをもつ熱可塑性エラストマー, 結晶性のハード グメントをもつ熱可塑性エラストマーの順に大きくなっ た.この結果は, 結晶相などの塑性変形により外力を吸 収できる領域を有する凝集組織が耐疲労性材料に必要で あることを示している. 同一ハードセグメントを有する TU- $M_{n}$ の場合, PTMG の $M_{n}$ の増加とともに $H_{0}$ と $C$ は低下した。 これは同一変形量でのヒステリシス損失 が PTMGの $M_{n}$ が小さいほど大きいという事実に起因し ている.ハードセグメントの凝集力の強いBiomer®は, ほぼ同一ソフトセグメント長の TU 2000 に比べて $H_{0}$, Cともに大きな値を示した.

3.3.4 疲労後のミクロ相分離搆造 Fig. 12 は疲労直 後及び疲労後 24 時間室温に放置し疲労回復したTU 856 の動的粘弾性挙動の温度依存性である. 疲労に伴いカラ ス状態の $E^{\prime}$ は低下したが, 24 時間回復後は $\alpha_{\mathrm{a}}$ 吸収温 度域より低温側の $E^{\prime}$ はほぼ元の值に戻っている， $\alpha_{\mathrm{a}}$ 吸 収は疲労に伴い約 $10 \mathrm{~K}$ 高温側に移動し, $\tan \delta$ のピー ク值及び $\alpha_{\mathrm{a}}$ 吸収の活性化エネルギーが増加した。2 24 時 間回復後は, $\tan \delta$ のピーク值は更に増加したが, $\alpha_{\mathrm{a}}$ 吸 収の高温側へのシフトは小さくなり, 活性化ェネルギー は疲労直後とほぼ同一の值を示した．他方, コム状態で は，疲労直後に著しい $E^{\prime}$ の低下が観測され，ハードセ グメントの融解に起因する $E^{\prime}$ の減少も $370 \mathrm{~K} と$ Original 試料に比べて 低温で起こった. 24 時間回復後は, コム状態の $E^{\prime}$ の低下む小さく，ハードセグメントの融 解も $450 \mathrm{~K}$ 付近で始まったここれらの結果より, 疲労 


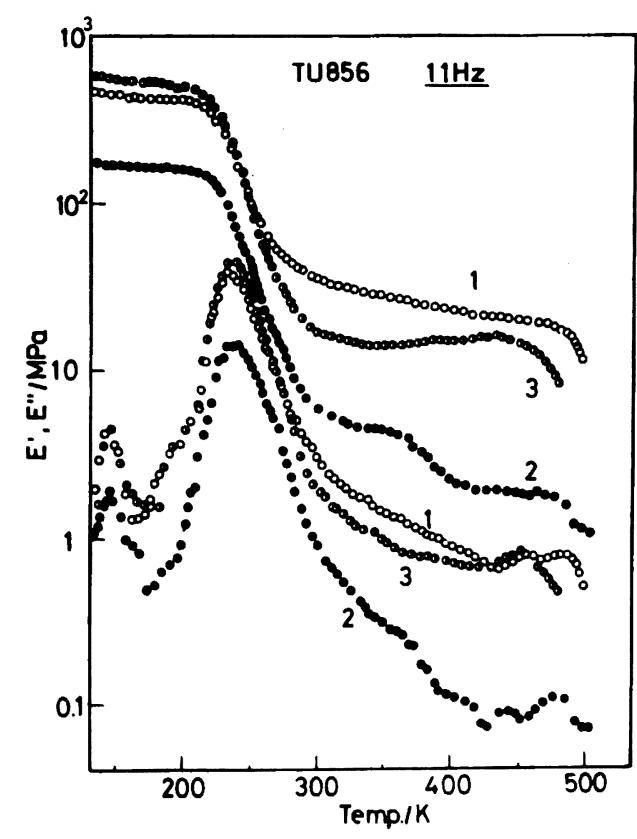

Fig. 12. Temperature dependences of $E^{\prime}$ and $E^{\prime \prime}$ of TU856 after cyclic fatigue: 1, original; 2 , fatigued (strain amplitude $120 \%$, time $10^{4} \mathrm{~s}$ ); 3 , fatigued (strain amplitude $120 \%$, time $10^{4} \mathrm{~s}$ ) and recovered at $295 \mathrm{~K}$ for $24 \mathrm{~h}$.

に伴い分子鎖が変形方向に配向し緊張するとともに， 八 ートセグメントとソフトセグメントの部分的な混合が起 こっていることが予想される。このためハードセグメン トが高温で有効な橋かけ点として働かず， $E^{\prime}$ が低温で 低下し始め， $\alpha_{\mathrm{a}}$ 吸収もハードセグメント相とソフト七 グメント相の部分的な混合によって高温にシフトすると 考えられる.7 日間以上回復した試料でも $\alpha_{\mathrm{a}}$ 吸収ピー ク温度域は, Original試料に比べて高温側にあり，ピー クもブロードであることから, 疲労に伴ら相分離の進行 は生じていない.

Fig. 13 は疲労直後と疲労後 24 時間室温で回復した TU 856 の広角X線回折強度のブラッグ角依存性であ る. 図中実線は赤道方向, 破線は子午線方向の走査を示 寸. 疲労に伴い $2 \theta=19.9^{\circ}$ の PTMG の非晶ハローが 赤道上に強度を增し, その後, $2 \theta=7.5^{\circ}$ のハードセグ ×トの 1 繰返し単位の距離に相当する反射が子午線上に 強度を増した。この結果は, 繰り返し変形を与えると, まずソフトセグメントが配向し，その後，ハードセグメ ントが配向することを示している. 配向は,ひずみ振幅 が大きいほど, PTMG の $M_{n}$ が小さいほど短時間で起 こった. 室温で 24 時間回復した試料の場合, ソフトセ グメントの配向は小さくなったが，ハードセグメントの 配向はほとんど変化しない。

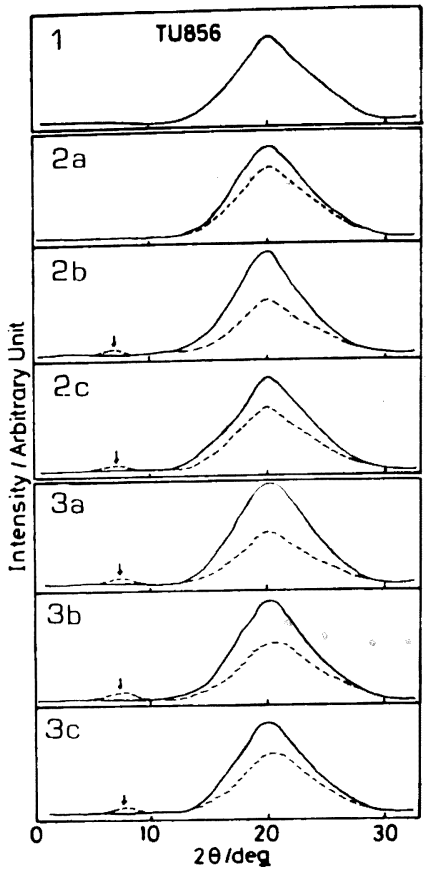

Fig. 13. Angular dependences of wide angle X-ray diffraction intensities for TU856 after cyclic fatigue: 1 , original, $2 a$, fatigued (strain amplitude $50 \%$, time $10^{4} \mathrm{~s}$ ), $2 \mathrm{~b}$, fatigued (strain amplitude $50 \%$, time $\left.1.5 \times 10^{5} \mathrm{~s}\right), 2 \mathrm{c}$, fatigued (strain amplitude $50 \%$, time $1.5 \times 10^{5} \mathrm{~s}$ ) and recovered at $295 \mathrm{~K}$ for $24 \mathrm{~h}, 3 \mathrm{a}$, fatigued (strain amplitude $120 \%$, time $10^{3} \mathrm{~s}$ ), $3 \mathrm{~b}$, fatigued (strain amplitude $120 \%$, time $10^{4} \mathrm{~s}$ ), $3 \mathrm{c}$, fatigued (strain amplitude $120 \%$, time $10^{4} \mathrm{~s}$ ) and recovered at $295 \mathrm{~K}$ for $24 \mathrm{~h}$.

\section{4 結 論}

種々のソフトセグメント長を有するセグメントポリウ

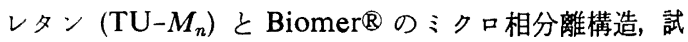
料之血小板の相互作用, 疲労挙動を検討した. 小角X線 散乱, 動的粘弾性, 及び IR スペクトル測定の結果より ソフトセグメントの PTMG の分子量, $M_{n}$ の増加とと もに, ミクロ相分離構造の大きさが増加し相分離状態が より完全になることが明らかになった。 ミクロ相分離状 態が完全である Biomer®と TU 2000 の場合, 血小板 の粘着数は少なく、形態变化も抑制された，疲労寿命 は, 同一ひずみ振幅での材料間の差異は小さいが, 疲労 破壊に至るまでの真のヒステリシス損失を考虑すると, ハードセグィントの凝集力の強い Biomer®が高い疲労 強度を示した. 疲労に伴いソフトセグィントとハードセ グィントの配向や両相の部分的混合が観測された。 
朝 辞 ヒト多血小板血獎を提供していただいた九州 大学医学部付属病院輸血部の方々に樑く感謝致します.

\section{文献}

1) R. Bonart, Angew. Makromol. Chem., 58/59, 259 (1977).

2）木村逸郎，鈴木 㹂，斉藤勝男，石原英昭，小 野 浩, 工業化学雑誌, 73, 594 (1970).

3) J. W. Boretos and W.S. Pierce, Science, 158, 1481 (1967).

4) J. W. Boretos, W. S. Pierce, R.E. Bair, A. F. Lory, and H. J. Donachy, J. Biomed. Mater. Res., 9, 327 (1975).

5) D. J. Lyman, F. J. Fazzio, H. Voorhees, G. Robinson, and D. Albo, Jr., J. Biomed. Mater. Res., 12, 337 (1978).

6) 渥美和彦, 人工臟器, 10, 712 (1981).

7) J. L. Brash, B. K. Fritzinger, and S. D. Bruck, J. Biomed. Mater. Res., 7, 313 (1973).

8) 高原 淳, 田下純一, 山田憲二, 梶山千里, 高 柳素夫，第 2 回日本パイオマテリアル学会大会 論文集, p. 101 (1980).

9) A. Takahara, K. Yamada, T. Kajiyama, and M. Takayanagi, J. Appl. Polym. Sci., 25, 597 (1980).

10) A. Takahara, K. Yamada, T. Kajiyama, and M. Takayanagi, J. Appl. Polym. Sci., 26, 1085 (1981).

11) J. E. Mark, J. Am. Chem. Soc., 88, 3708
(1968).

12) K. Nakayama, T. Ito, and I. Matsubara, J. Macromol. Sci,. Chem., A3, 1005 (1969).

13) H. Ishihara, I. Kimura, K. Saito, and H. Ono, J. Macromol. Sci., Phys., B10, 591 (1974).

14) 石原英昭, 木村逸郎，材料科学, 9, 244 (1972).

15) G. L. Wilkes and S. Abouzahr, Macromolecules, 14, 456 (1981).

16) S. Krause, Macromolecules, 3, 84 (1970).

17) R. Rajaraman, D. E. Rounds, S.P.S. Yen, and A. Rembaum, Exp. Cell. Res., 88, 327 (1974).

18）与那覇朝英, 出月康夫, 浜口実, 渡辺弘, 森 有一, 長岡昭二, 菊池哲也, 丹沢 宏, 人 工臟器, 9, 228 (1980).

19) D. J. Lyman, K. Knutson, B. McNeil, and K. Shibatani, Trans. Am. Soc. Artif. Int. Organs, 21, 49 (1975).

20）松田武久, 林紘三郎, 高野久輝, 妙中義之, 梅津光生, 中村孝夫, 野村春治, 第 3 回日本バ イオマテリアル学会大会論文集, p. 21 (1981).

21) V.S. da Costa, D. Brier-Russel, G. Trudel, III, D. F. Waugh, E. W. Salzman, and E. W. Merrill, J. Colloid. Interface Sci., 76, 594 (1980).

22) A. Takahara, K. Yamada, T. Kajiyama, and M. Takayanagi, J. Mater. Sci., 15, 2653 (1980).

Influence of Microphase Separated Structure of Segmented Polyurethane on Its Antithrombogenicity and Fatigue Behavior

Atsushi Takahara, ${ }^{* 1}$ Junichi Tashita, ${ }^{* 1}$ Tisato KaJIYAma, ${ }^{* 1}$ and Motowo Takayanagi*1

${ }^{* 1}$ Department of Applied Chemistry, Faculty of Engineering, Kyushu University (10-1, Hakozaki 6-chome, Higashi-ku, Fukuoka, 812 Japan)

This report describes microphase separated structure, antithrombogenicity, and fatigue behavior of Biomer ${ }^{\circledR}$ or segmented polyurethane with various soft segment lengths. The small angle X-ray scattering pattern showed existence of the superstructure with long period, which indicates that the hard and soft segments of segmented polyurethane form microphase separated structure. With an increase of the molecular weight of poly(tetramethylene glycol) (PTMG) in the soft segment, the long period increased and the glass transition temperature of the soft segment and the extent of hydrogen bonding in urethane carbonyl decreased. Thus, the microphase separated structure is reorganized more distinctly with an increase of the molecular weight of PTMG. The antithrombogenicity of segmented polyurethane was investigated on the basis of the number of adhered platelets and of their morphology on its surface. The antithrombogenicity was improved with an increase of the molecular weight of PTMG. The fatigue strength is closely related to the net hysteresis loss upto the fatigue failure, which is larger for the samples with strongly aggregated hard segment or with low molecular weight PTMG. During cyclic fatigue, the mixing of hard and soft segment phases proceeds to some extent.

KEY WORDS Biomedical Polymer / Segmented Polyurethane / Biomer / Microphase Separated Structure /

Antithrombogenicity / Blood Compatibility / Blood Platelet / Fatigue / Hysteresis Loss /

(Received October 24, 1981: Accepted January 31, 1982)

[Kobunshi Ronbunshu, 39 (4), 203-211 (1982)] 